\title{
FLOW UNDER THE ISLAND ARC OF JAPAN AND LATERAL VARIATION OF MAGMA CHEMISTRY OF ISLAND ARC VOLCANOES
}

\author{
Mitsuhiro TorIUMI* \\ University Museum, University of Tokvo, Tokyo, Japan \\ (Received May 31, 1978; Revised September 8, 1978)
}

\begin{abstract}
Dislocation densities of olivine grains in peridotite nodules from Ichinomegata (25 samples), Sannomegata (18 samples), Oki-Dogo (13 samples), Hamada (3 samples) and Takashima (10 samples) were measured for estimating differential stress in the upper mantle. The density was in the range of $10^{6}-10^{7} \mathrm{~cm}^{-2}$. The differential stress is estimated as 100-300 bars using KOHLSTEDT and GoETzE's empirical relationship (1974) between the dislocation density and the differential stress. Strain rate is inferred from the geotherm of the island arc and the flow law of olivine single crystal proposed by KoHLSTEDT and GoEtze (1974) and Durham and Goetze (1977). Strain rate in the upper mantle from 30 to $100 \mathrm{~km}$ depth is less than $10^{-15} \mathrm{sec}^{-1}$, but it is nearly constant around $10^{-13}-10^{-12} \mathrm{sec}^{-1}$ from 100 to $200 \mathrm{~km}$ depth.

The convective flow induced by descending oceanic plate is suggested and the velocity of the return flow is estimated to be $5 \mathrm{~cm} /$ year. The return flow of the upper mantle toward the trench causes the lateral variation of magma chemistry and the upper mantle materials, if partially molten liquid continuously fows out from the moving upper mantle. The model in this study gives a relation between the horizontal distance from the volcanic front, $X$, and the concentration ratio of $C_{\mathrm{f}}{ }^{1} / C^{1}\left(C_{\mathrm{f}}{ }^{1}\right.$; concentration at volcanic front $)$ as follows;

$$
C_{f^{1}} / C^{1}=\exp (-\beta \phi X / v),
$$

in which $\beta$ and $v$ are the rate of outflow of the liquid per unit volume of the upper mantle and the mean velocity of the return flow, and $\phi$ is a constant.
\end{abstract}

\section{Introduction}

Convective flow of the upper mantle materials under the island arc induced by subducting oceanic plate (SLeEp and Toksöz, 1971) contributes to heat transportation and chemistry of mantle materials. Heat transportation by convective flow gives a great effect on the temperature distribution and, therefore, the state of partial melting in the upper mantle. Convective flow also affects the chemistry of partially molten liquid because of continuous outflow of partially molten liquid from the moving mass. They are important to the magma chemistry of the island arc, the chemistry of the upper mantle materials, and the opening of the Back Arc Basin (Sleep and Toksöz, 1971).

Actual flow can be demonstrated by measuring the differential stress acting within the upper mantle, which is estimated from the dislocation density or the subgrain size of olivine derived from the upper mantle. The experimental relations between the dislocation density and the differential stress have been obtained by KoHLSTEDT and GoETzE (1974) and

* Present address: Earth Sciences, Faculty of Science, Ehime University, Matsuyama, Ehime, 930 Japan. 


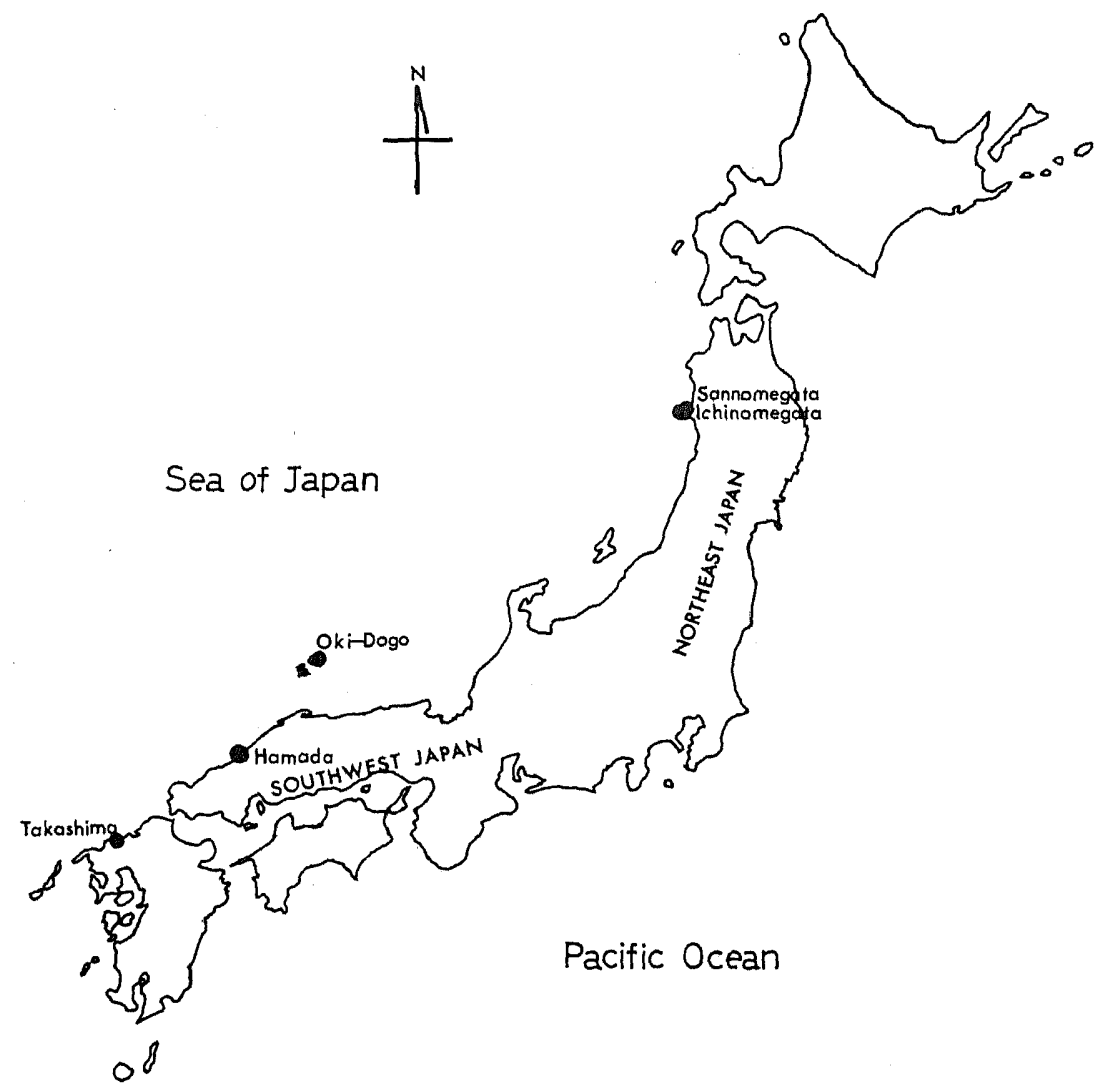

Fig. 1. Localities of mantle derived xenoliths.

Durham et al. (1977), and those between the subgrain size and differential stress also have been proposed by Durfam et al. (1977). Further, decrease of the dislocation density in static annealing has been investigated by Goetze and KOHLSTEDT (1973), and Torium and Karato (1978). Combining these data, the differential stress of the upper mantle could be estimated by means of the dislocation density or the subgrain size of the mantlederived olivine grains.

If we can estimate the differential stress, the strain rate of the upper mantle should be inferred by the geotherm and empirical flow law. Thus, the author intends to discuss the strain rate and flow in the upper mantle beneath the Island Arc of Japan, based on the dislocation density of the mantle-derived olivine in peridotite xenoliths of Japan. Further, he proposes a zone refining model of the upper mantle due to the upward outflow of the partially molten liquid from the moving upper mantle. The model can interpret the lateral variation of magma chemistry of the island arc volcanoes.

\section{Brief Descriptions of Peridotite Xenoliths}

Xenoliths studied here are from Ichinomegata (25 samples), Sannomegata (18 samples), Oki-Dogo (13 samples), Hamada (3 samples), and Takashima (10 samples). They 
are included in alkali basaltic lavas and breccias. Ichinomegata and Sannomegata are located in the Northeast Japan Arc, and Oki-Dogo, Hamada and Takashima are in the Southwest Japan Arc (Fig. 1). The volcanic rocks including the peridotite xenoliths erupted at a time of 0-3 my. Petrology of Ichinomegata peridotite xenoliths has been studied by Kuno and AOKI (1970), AOKI (1973) and TAKahashr (1976), and that of OkiDogo by TaKaHashi (1976). Petrological studies of Hamada and Takashima peridotite xenoliths have been carried out by FujIr (1974) and OBATA (1972), respectively.

Most of the xenoliths are amphibolite, granulite, hornblende gabbro, olivine-pyroxene gabbro, spinel lherzolite, hornblende-spinel lherzolite, plagioclase-spinel lherzolite, dunite, wherlite, and websterite. It is important that there is a certain difference between the Northeast Japan Arc (Ichinomegata, and Sannomegata) and the Southwest Japan Arc (Oki-Dogo, Hamada and Takashima). In Ichinomegata and Sannomegata, spinel lherzolite including hornblende is common, but the spinel lherzolite does not contain hornblende at other localities.

Petrological difference in xenoliths at a single locality probably leads to a layered model of the upper mantle. FujI (1974) and TAkAfashr (1976) have suggested the layered model of the upper mantle consisting with spinel lherzolite, dunite and pyroxenite layers with ascending order. The upper mantle under Ichinomegata and Sannomegata are also considered to be stratified with spinel lherzolite, wherlite, dunite and pyroxenite layers (Takahashi, personal communication, 1978). The structure of the upper mantle is. probably formed through a crystallization differentiation process in the magma reservoir within the upper mantle (Fujr, 1974).

Equilibration temperature of spinel therzolite has been estimated using orthopyroxeneclinopyroxene, olivine-clinopyroxene, and spinel-olivine geothermometers by Fujn (1974) for Hamada, Obata (1972) for Takashima, and TAkafashr (1976) for Oki-Dogo and Ichinomegata. Most of spinel therzolite xenoliths show the equilibration temperature of $900-1,000^{\circ} \mathrm{C}$ but pyroxenite xenoliths show that of $700-900^{\circ} \mathrm{C}$. This supports the layered model of the upper mantle mentioned above.

\section{Dislocation Structure and Density}

TORIUmi and KARATo (1978) have recognized two types of dislocation structure of olivine grains; one is the cellular type (Fig. 2(A)) which consists of network of simple dislocation walls (small angle subboundaries), and the other is the tangled type (Fig. 2(B)) which is composed of tangled dislocations without simple dislocation walls. Simple dislocation walls are usually (100) subboundary (Fig. 2(C)), (010) (Fig. 2(D)), and (001) subboundaries. Most spinel lherzolite xenoliths in Ichinomegata, Sannomegata, and Oki-Dogo contain olivine grains of both types (TorIumI and KARATo, 1978), but all of dunite and olivine pyroxenite xenoliths of Takashima contain only equigranular grains of olivine with the cellular type dislocation structure. Cummulate group peridotites. (FujIr, 1974; TAKahashr, 1976) contain few grains of the cellular type olivine.

The cellular type dislocation structure is probably formed in the steady state creep, considering that the structure is similar to the dislocation structures of experimentally deformed MgO (Hütrer and Reppich, 1973) and LiF (Streb and Reppich, 1973) in the steady state creep. Recent works by DuRHAm et al. (1977) have also pointed out that the steady state dislocation structure of olivine at high temperature creep displays abundant (100) subboundaries which are one type of the dislocation walls in the cellular type dis- 

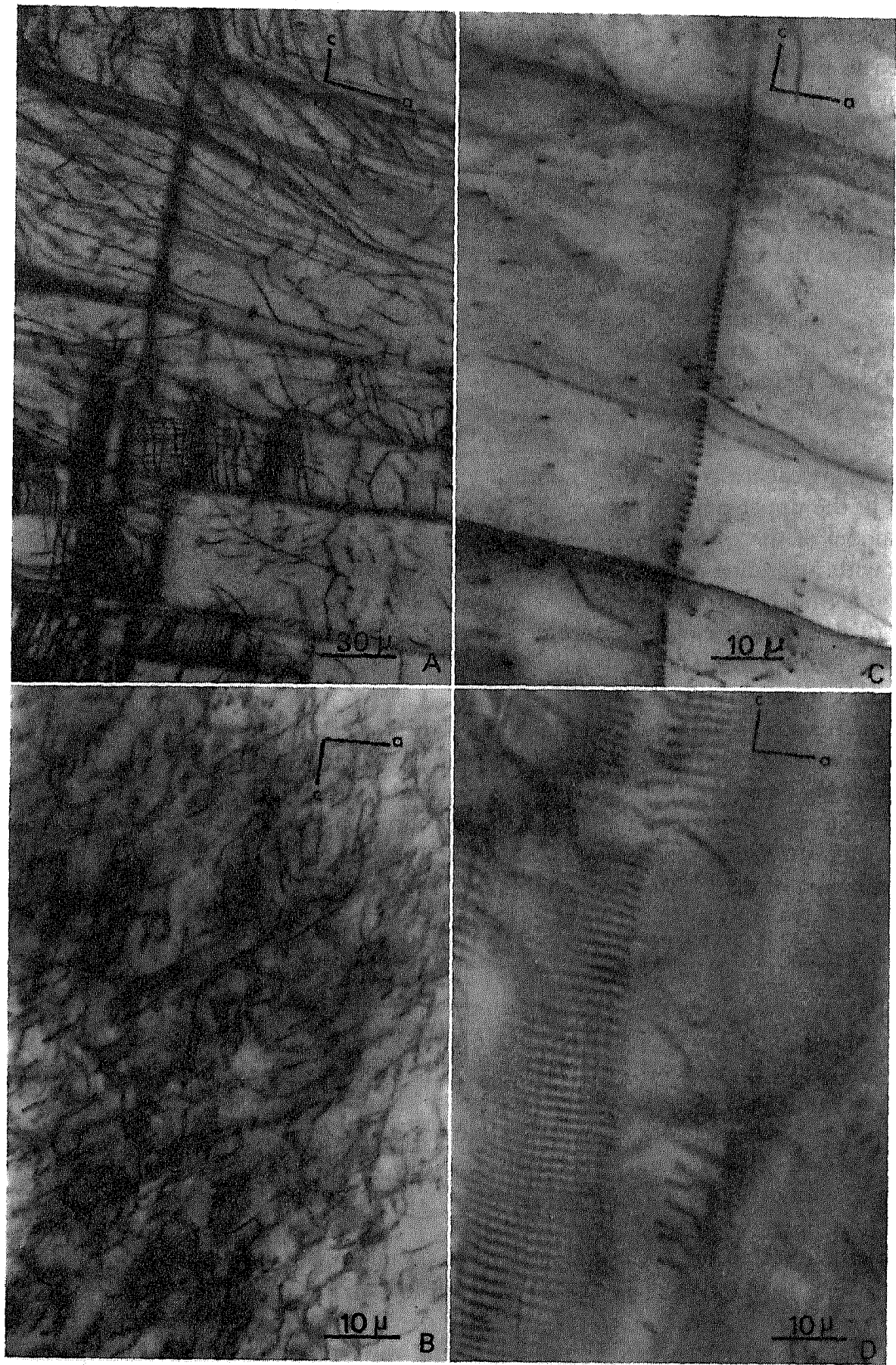

Fig. 2. Dislocation structures of olivine decorated by oxidation-decoration method of KoHLsTEDr and VANDER SANDE (1975). (A) Cellular dislocation structure. (100) and (001) subboundaries (dislocation walls) are recognized as the broadly dark lines. (B) Tangled dislocation structure without subboundary. Dislocations are tangled with each other. (C) (100) simple dislocation wall (small angle subboundary) showing the clear array of dislocation lines. (D) (010) simple network of dislocations (small angle twist boundary). 
location structure in this study. On the other hand, the tangled type structure is probably formed in the transient creep, judging from the fact that this structure appears very much alike the transient structure in DURHAM et al. (1977). Considering that the uppermost mantle possesses cummulated layers from liquid, the deformation of such layers may be in the transient state.

Taylor's equation $\sigma=\alpha G b \sqrt{\rho}$, in which $\sigma, \rho, G$, and $b$ are the differential stress, dislocation density, the rigidity, and the magnitude of the Burger's vector of olivine, respectively, is applied to the steady state creep, but not to the transient creep. This is because the dislocation density changes during transient creep and acheives a constant value in the steady state creep as investigated on olivine single crystals by DURHAM et al. (1977).

On the other hand, the subgrain size may provide an indicator of stress as suggested by Raleigh and KIRBY (1970) and Durham et al. (1977). The subgrain size is defined by the mean distance between simple dislocation walls (subboundaries). Durham et al. (1977) have proposed the relation, $d=45 \mathrm{~Gb} / \sigma$, in which $d$ is the subgrain diameter. As the formation of the simple dislocation walls has been considered to be in the steady state creep (Torium and Karato, 1978), the relation is also applicable to estimating the stress.

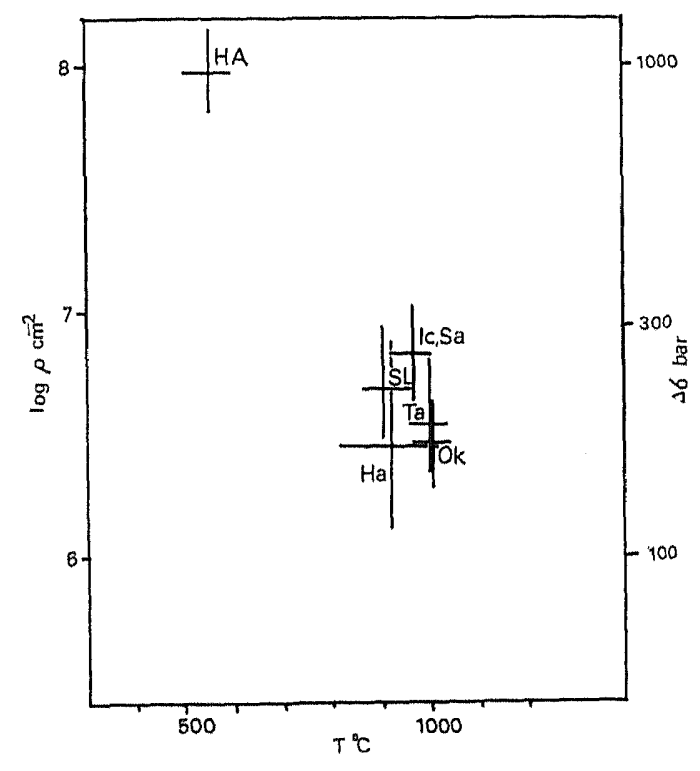

Fig. 3. Observed dislocation density ( $\rho$ )equilibration temperature diagram. Differential stress is estimated from KorrsstedT and GoETze's empirical equation (1974). Ic, Ichinomegata; Sa, Sannomegata; Ta, Takashima; Ok, Oki-Dogo; Ha, Hamada; SL, Salt Lake of Hawaii; HA, Higashi Akaishi dunite mass in Shikoku, Japan (TorIUMr, 1978).

Table 1. Dislocation densities and subgrain sizes of olivine.

\begin{tabular}{lll}
\hline Locality & Dislocation density $\left(\mathrm{cm}^{-2}\right)$ & Subgrain size $(\mu \mathrm{m})$ \\
\hline Ichinomegata (25)* & $6 \times 10^{6}-2 \times 10^{7}$ & $40-70$ \\
Sannomegata (18) & $5 \times 10^{6}-1 \times 10^{7}$ & $70-100$ \\
Oki-Dogo (13) & $2-5 \times 10^{6}$ & $100-160$ \\
Hamada (3) & $1-3 \times 10^{6}$ & $120-210$ \\
Takashima (10) & $2 \times 10^{6}-1 \times 10^{7}$ & $60-120$ \\
Salt Lake (16) & $4 \times 10^{6}-1 \times 10^{7}$ & $40-60$ \\
\hline
\end{tabular}

* Number of xenoliths. 
The ranges of the dislocation density and the subgrain diameter are listed in Table 1 , and are plotted in the temperature-logarithmic dislocation density diagram (Fig. 3). The temperature used are the equilibration ones as stated in the previous section.

The data of spinel lherzolite xenoliths (16 samples) of Salt Lake in Hawaii, of which equilibration temperatures have been estimated by MCGREGOR (1974), are added for reference. The figure shows that the dislocation densities and the differential stress of studied peridotite xenoliths are plotted in the narrow ranges of $10^{6}-10^{7} \mathrm{~cm}^{-2}$ and 100 300 bars, respectively, and they are quite similar to those of other localities studied by Gueguen (1977). The samples, however, were derived from different positions of the earth surface and different depths in the upper mantle under the Island Arc of Japan as mentioned above. Therefore, at least in the uppermost mantle the stress is probably constant around 100-300 bars, in other words, the stress gradient in the upper mantle is quite small. The stress is also in the same order as that in the oceanic plate deduced from Salt lake xenoliths (Fig. 3).

\section{Strain Rate}

Creep equation of the single crystals of olivine and peridotite has been investigated by Carter and Avelarlemant (1970), Kohlstedt and Goetze (1974), and Durham and Goetze (1977). Their results have indicated the power-law creep equation for the stress in which the power is 2-5. Most reliable data on single crystals of olivine have been proposed by Durham and Goetze (1977), and their results showed the power of 3-4. This value is quite close to that of the WeERTMAN (1968)'s model of steady state creep. They have also clarified that the creep process of olivine single crystals must be governed by the dislocation climb process, because independent slip systems have only three components and this fact is out of the Von Mises's criterion (Durham and Goetze, 1977). Further, the activation energy for the creep process obtained by KoHLsTed and GoEtze (1974) is quite close to that for annihilation process controlled by the dislocation climb (Torium and Karato, 1978). These facts strongly suggest that the steady state creep of olivine single crystal and also polycrystalline aggregates of olivine is mainly controlled by the dislocation climb process as stated by Weertman (1970) and Goetze and Kohlstedt (1973).

The Weertman type creep law becomes,

$$
\dot{\varepsilon}=A \sigma^{3} \exp \left(-\left(E_{\mathrm{o}}+P V^{*}\right) / R T\right)
$$

in which $\dot{\varepsilon}, \sigma, E_{0}$, and $V^{*}$ are strain rate, differential stress, activation energy, and activation volume of creep process, respectively. $A$ is a constant. STocker and Ashry (1973) have given $V^{*}=11-40 \mathrm{~cm}^{3} / \mathrm{mol}$, and $E_{\mathrm{C}}=150 \mathrm{kcal} / \mathrm{mol}$, but we assume $E_{\mathrm{C}}=125 \mathrm{kcal} / \mathrm{mol}$ and $V^{*}=14 \mathrm{~cm}^{3} / \mathrm{mol}$ (Karato, 1977). The coefficient $A$ is estimated as $20 \mathrm{sec}^{-1} \mathrm{bar}^{-3}$ from the least square fitting of Durham and GoEtze's data (1977). The high temperature experiments by Kohlstedt and Goetze (1974) and Durham and Goetze (1977) have been carried out in the $\mathrm{H}_{2}-\mathrm{CO}_{2}$ gas mixture, and consequently the creep of olivine crystals probably proceeds in somewhat wet conditions. As stated by GrIGGS (1974) on $\mathrm{SiO}_{2}$ aggregates, the component $\mathrm{OH}^{-1}$ can agitate the glide mobility of dislocations. It still remains as a problem whether the component $\mathrm{OH}^{-1}$ also affects the climb mobility of dislocations, which controls the steady state creep. Climbing of dislocations is made by emitting oxygen or vacancy toward other dislocations or by absorbing one (NABARRo, 1967). Thus, the dislocation climb is governed by diffusion of oxygen. As the diffusivity 


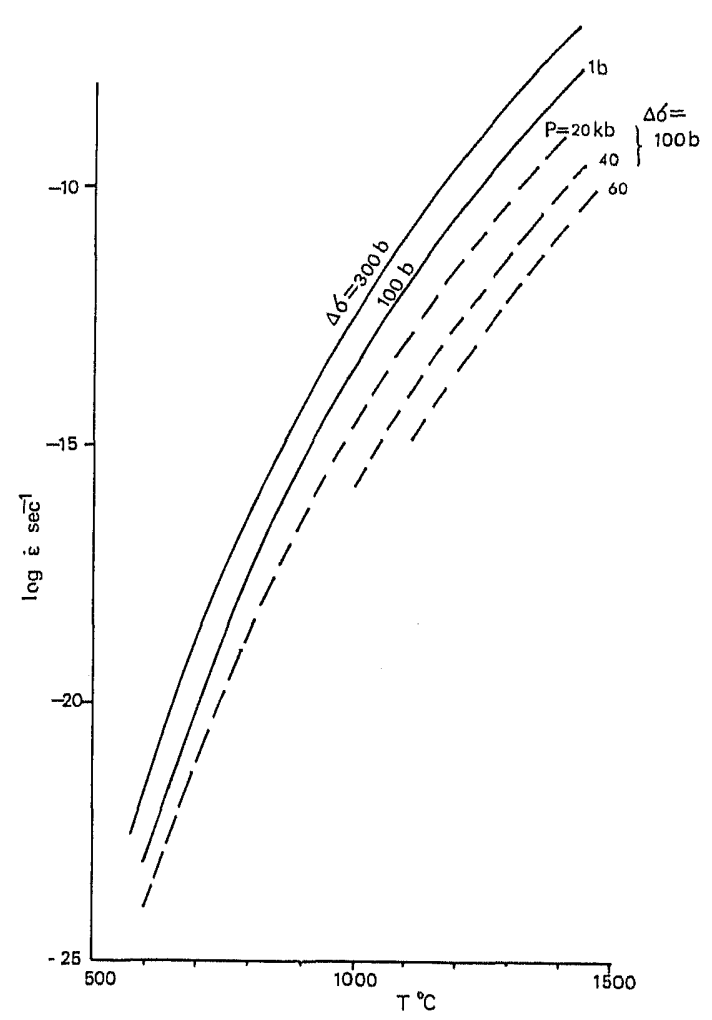

Fig. 4. Isostress curves under various hydrostatic pressures in temperaturestrain rate diagram.

of oxygen in crystal probably depends on the concentration of $\mathrm{OH}^{-1}$ ion, it is suggested that the climb mobility of dislocations, that is, the creep rate is somewhat affected by presence of that ion. However, as we have no data on creep equation depending upon the content of $\mathrm{H}_{2} \mathrm{O}$ in olivine, it is assumed in this paper that the upper mantle materials contain some amounts of $\mathrm{H}_{2} \mathrm{O}$ or that the $\mathrm{OH}^{-1}$-dependence of creep equation is negligible.

In Fig. 4, the isostress curves calculated from the creep equation are shown in a temperature versus strain rate diagram for various hydrostatic pressures. In this diagram, we also ignore the Nabbaro-Herring and Coble creep which are proceeded by oxygen-self diffusion because they are predominant in very low stress and high temperature region (STOCKer and Astrix, 1973). It is suggested that the strain rate depends mainly on temperature but slightly on stress and pressure within the range of variation of them as shown in Fig. 4.

\section{Temperature Distribution under the Island Arc}

As stated in the previous sections, the temperature distribution of the upper mantle is quite important for calculating strain rate in the upper mantle. The temperature distribution under island arc has been simulated using some geophysical constraints by HASEBE et al. (1970), Toksöz et al. (1971) and others. They have weighted on the surface heat flow of the island arc and the temperature distribution on the surface of the descending slab. But, their temperature distributions cannot explain the petrological data on perido- 


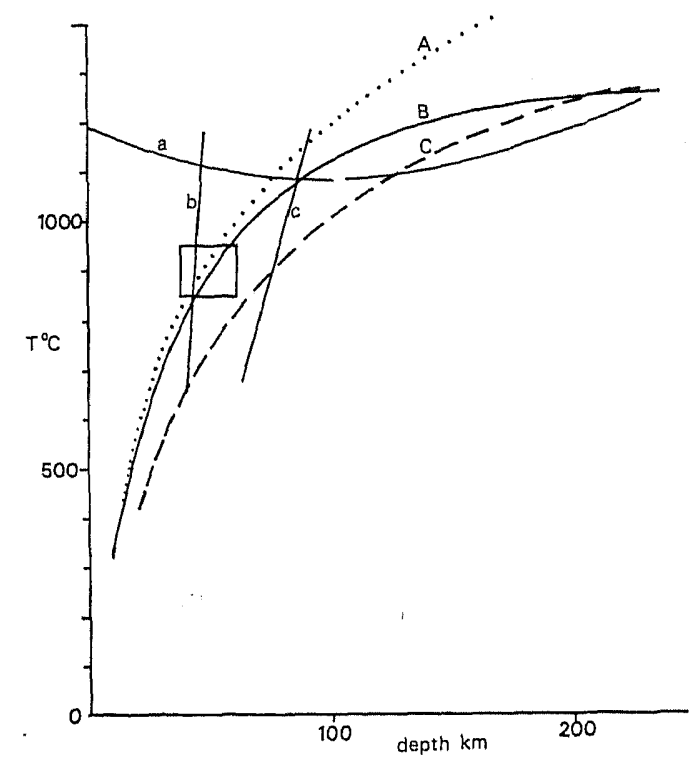

Fig. 5. Temperature distribution under island arc. A, Toksöz et al. (1971); B, geotherm used in this paper; $\mathrm{C}, \mathrm{HA}_{\mathrm{A}}$ SEBE et al. (1970). a, wet solidus of periclotite by Kuswrino et al. (1968); b, boundary between plagioclase and spinel peridotite; c, boundary between spinel and garnet peridotite (Kusmrro and YODER, 1966). Square shows the possible conditions of studied spinel lherzolite xenoliths in Japan.

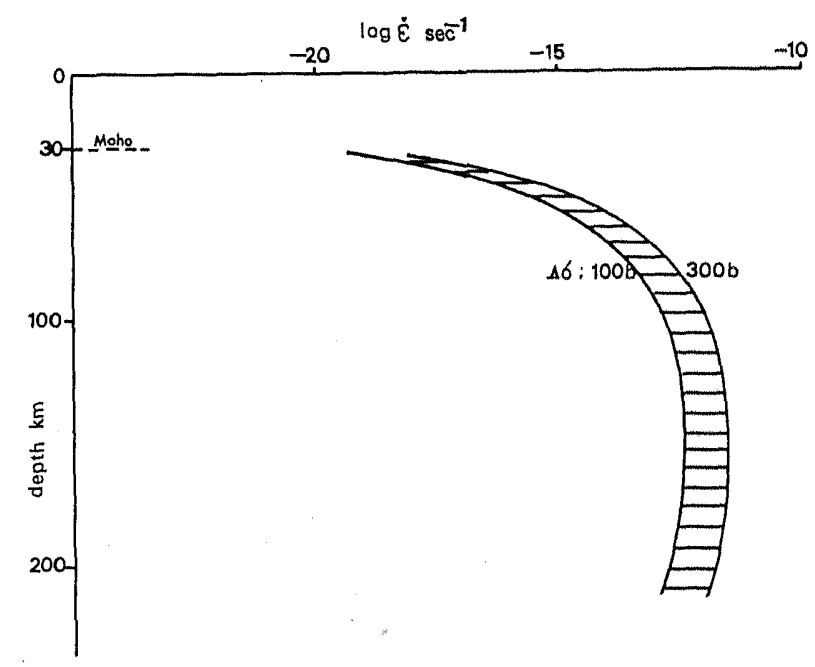

Fig. 6. Strain rate distribution in the upper mantle under the Island Arc of Japan.

tite xenoliths and seismological data. As clarified by OBATA (1972), Fujn (1974) and TAKAFAsmr (1976), peridotite xenoliths of the Island Arc of Japan are commonly spinel lherzolite and plagioclase-spinel lherzolite, and their equilibration temperatures are ranging from 900 to $1,000^{\circ} \mathrm{C}$. As shown in Fig. 5, these data are deviated toward high temperature regions from the geotherm by HASEBE et al. (1970) under the Back Arc region. On the other hand, the geotherm by Toksöz et al. (1971) is running across the region much above solidus of wet peridotite (Kustiro et al., 1968) below $70 \mathrm{~km}$ depth. FujIsAWA (1968) has deduced the temperature of $1,300 \pm 100^{\circ} \mathrm{C}$ at $375 \mathrm{~km}$ depth near Japan, combining the experimental condition of spinel-olivine transition and seismological data. 
In this paper, we use a geotherm B in Fig. 5 of which shallower part is close to Toksöz et al.'s geotherm (1971) and deeper part to HASEBE et al.'s one (1970). This assumption means a high thermal conductivity of the upper mantle compared with that of HASEBE et al. (1970) due to rising partially molten liquid. The geotherm B satisfies the surface heat flow of 2.0-3.0 HFU.

\section{Strain Rate Distribution in the Upper Mantle}

Strain rate distribution in the upper mantle can be estimated under the assumption of negligible effect of partial melting on it. Though a large degree of partial melting, of course, can make the strain rate increase, presence of liquid less than some per cents does not probably increase the strain rate (STOckeR and Ashby, 1973). In this paper the strain rate of the upper mantle is inferred from the flow law of olivine single crystals proposed by Kohlstedt and Goetze (1974) and Durham and Goetze (1977) as mentioned previously. Figure 6 shows the strain rate as a function of depth. An increase of strain rate from 30 to $100 \mathrm{~km}$ depth of the upper mantle is governed almost by the geothermal gradient, but below $100 \mathrm{~km}$ depth it is affected by the pressure.

It is important that the strain rate in the upper mantle of $100-200 \mathrm{~km}$ depth is relatively uniform around $10^{-13}-10^{-12} \mathrm{sec}^{-1}$, and it abruptly decreases with decreasing depth. The mantle from 30 to $100 \mathrm{~km}$ depth is, therefore, considered as a rigid layer and that below $100 \mathrm{~km}$ depth is a soft layer. The corresponding Newtonian viscosity, defined as $\eta=\sigma \mid \dot{\varepsilon}$, of the soft layer is about $10^{15}-10^{17}$ poise, and that of the rigid layer is $10^{18}$ $10^{28}$ poise.

Flow velocity can be inferred under the assumption of laminar flow of the upper mantle beneath the Island Arc. The boundary conditions in this study are taken at the Moho surface and the surface of the descending slab as follows:

and

$$
v_{X}=0 \text { at Moho surface }(z=30 \mathrm{~km}) \text {, }
$$

$$
v_{X}=-10 \mathrm{~cm} / \text { year at slab surface }(z=200 \mathrm{~km}) \text {. }
$$

Here, we consider the horizontal velocity $\left(v_{X}\right)$ toward the trench as a fundtion of depth, $z$. Velocity profile $v_{X}(z)$ is calculated as follows. The mass balance in the mantle wedge

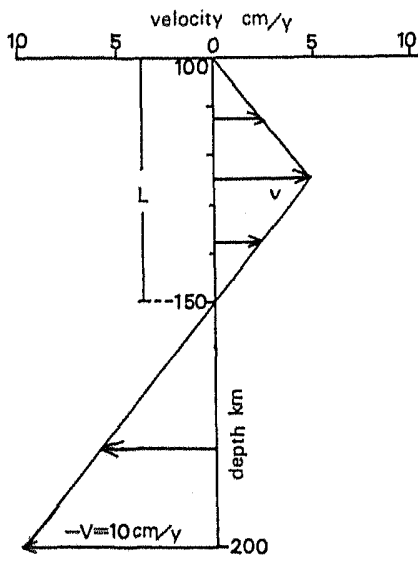

Fig. 7. A simple model of velocity profile at the reference cross section of which depth to the seismic zone is $200 \mathrm{~km}$ of the upper mantle of the Island Arc of Japan. The drag flow induced by descending slab is in the range of $150-200 \mathrm{~km}$ depth, and the return flow with thickness, $L$, is in 100-150 $\mathrm{km}$. 


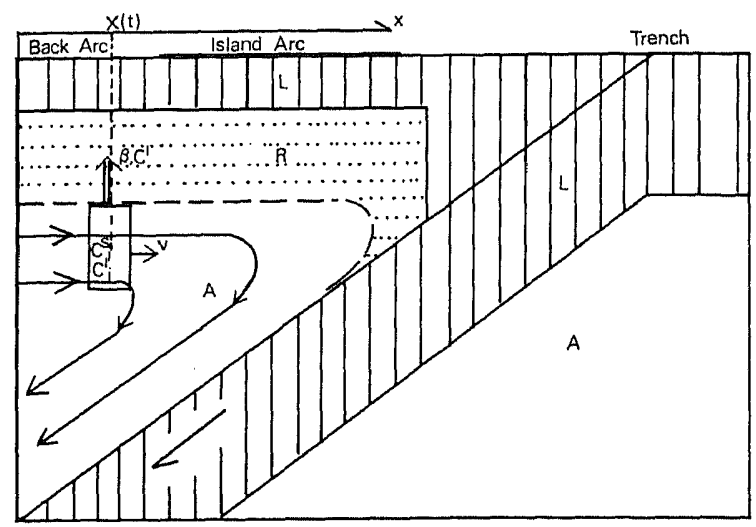

Fig. 8. A model of convective flow in the upper mantle under the Island Arc. L, lithosphere; A, asthenosphere; $\mathrm{R}$, rigid mantle with strain rate less than $10^{-15} \mathrm{sec}^{-1}$. Other symbols refer in text.

can be considered at a reference cross section of which depth to the slab surface is $200 \mathrm{~km}$ (Fig. 7). As stated in the previous sections, the strain rate of the mantle from 30 to 100 $\mathrm{km}$ depth is very small, and it is nearly constant around $10^{-13}-10^{-12} \mathrm{sec}^{-1}$ from 100 to 200 $\mathrm{km}$ depth. Therefore, the velocity gradient of the mantle flow should be assumed to be constant from 100 to $200 \mathrm{~km}$ depth. In this case, the drag flow of the mantle by descending slab induces the return flow in the shallower mantle as shown in Fig. 7. If the maximum velocity of the return flow is $v(\mathrm{~cm} /$ year), and the thickness of the return flow is $L(\mathrm{~km})$, we have,

and

$$
2 L v=10(100-L) \quad \text { (mass balance), }
$$

$$
2 v / L=10 /(100-L) \quad \text { (constant strain rate). }
$$

Combining Eq. (2) with Eq. (3), we obtain

$$
L=50 \mathrm{~km} \text { and } v=5 \mathrm{~cm} / \text { year. }
$$

At this time, the strain rate becomes $3 \times 10^{-14} \mathrm{sec}^{-1}$, being quite close to the estimated strain rate in the earlier section.

\section{Lateral Variation of Magma Chemistry of the Island Arc Volcanoes}

The convective flow of the upper mantle under the Island Arc gives a great effect on chemistry of partially molten liquid and the upper mantle materials. Considering the continuous outflow of partially molten liquid from the moving upper mantle, we can easily expect the zone refining of the upper mantle materials. In this section, the simple model, in which the liquid supply from the deeper mantle into the moving upper mantle is zero, is considered. Rate of the upward outflow of liquid per unit volume of the mantle is $\beta$ (year ${ }^{-1}$ ) and the concentrations of a volatile component such as $\mathrm{K}_{2} \mathrm{O}$ are $C^{1}$ in liquid, and $C^{\mathbb{S}}$ in solid phase (mantle material). It is assumed that the degree of partial melting $(\alpha)$ is constant and very small in the moving upper mantle and the velocity ( $\mathrm{v} \mathrm{km} /$ year) of the return flow is also constant. Considering $C^{1}(x ; t)$ and $C^{\mathrm{s}}(x ; t)$ at the distance, $x$, toward the trench in the two dimensional model as shown in Fig. 8 , the concentrations at $x+\delta x$ becomes $C^{1}+\delta C^{1}$ and $C^{\mathrm{s}}+\delta C^{\mathrm{s}}$ after $\delta t$, and volume of the outflow of liquid with 
$C^{1}$ is $\beta \delta t$. Therefore, we get the following equation of mass balance of the component; $\alpha C^{1}+(1-\alpha) C^{\mathrm{s}}=\alpha(1-\beta \delta t)\left(C^{1}+\delta C^{1}\right)+C^{1} \beta \delta t+(1-\alpha)(1-\beta \delta t)\left(C^{\mathrm{s}}+\delta C^{\mathrm{s}}\right)$.

Assuming the constant concentration ratio $k=C^{\mathrm{s}} / C^{1}$, Eq. (4) becomes,

$$
\delta C^{1} / C^{1}=-\beta \phi \delta t
$$

$$
\text { with } \phi=(1-k-\alpha) /(\alpha+k) \text {. }
$$

If $\alpha$ is very small against $k$, Eq. (5) becomes

$$
\phi \doteqdot(1 / k-1)
$$

Combining Eq. (5) with $v \delta t=\delta x$, we obtain,

$$
\delta C^{1} / C^{1}=-\beta \phi \delta x / v \text {. }
$$

Integrating Eq. (8), we have,

$$
C^{1} / C_{0}^{1}=\exp (-\beta \phi x / v)
$$

In which $C_{0}{ }^{1}$ is a constant.

Therefore, the concentration ratio $C_{\mathrm{f}} 1 / C^{1}$, in which $C_{\mathrm{f}}{ }^{1}$ is the concentration of the volatile component in the liquid at the volcanic front, becomes,

$$
C_{\mathrm{f}}{ }^{1} / C^{1}=\exp (-\beta \phi X / v),
$$

where $X$ is the distance from the volcanic front, $x_{\mathrm{f}}-x$.

Consequently, it is suggested that the concentration of a volatile component $(k<1)$ decreases toward the volcanic front in the upper mantle materials and in the partially molten liquid. Applying Eq. (10) to the lateral variation of magma chemistry of the Island Arc volcanism, we must know the rate of upward outflow of liquid and the mean velocity of the return flow of the upper mantle.

According to Nakamura (1974) and Sugimura (1974), the eruption rate of volcanic rocks is estimated to be $10^{-2}-10^{-3} \mathrm{~km}^{3} /$ year $\times 100 \mathrm{~km}$ in the Island Arc of Northeast Japan. Taking the width of the Island Arc of Japan as $200 \mathrm{~km}$ and the thickness of the return flow as $50 \mathrm{~km}$ as discussed in the previous section, the rate of outflow, $\beta$, should be approximated as $10^{-8}-10^{-9}$ year ${ }^{-1}$. Consequently, if the mean velocity of the return flow is $10^{-5} \mathrm{~km} /$ year, and the concentration ratio, $k$, is 0.1 for $\mathrm{K}_{2} \mathrm{O}$, the amplification factor, $\beta \phi / v$ is in the order of $10^{-2}-10^{-3} \mathrm{~km}^{-1}$. Figure 9 shows the theoretical changes of $\mathrm{K}_{2} \mathrm{O}$-content in liquid for various eruption rates.

Hatherton and Dickinson (1969) and Nielson and Storber (1973) have suggested that the $\mathrm{K}_{2} \mathrm{O}$-content both in basaltic adnesite $\left(\mathrm{SiO}_{2}=55 \mathrm{wt} \%\right)$ and andesite $\left(\mathrm{SiO}_{2}=\right.$ $60 \mathrm{wt} \%$ ) decreases toward the volcanic front from the Back Arc region. The lateral vari-

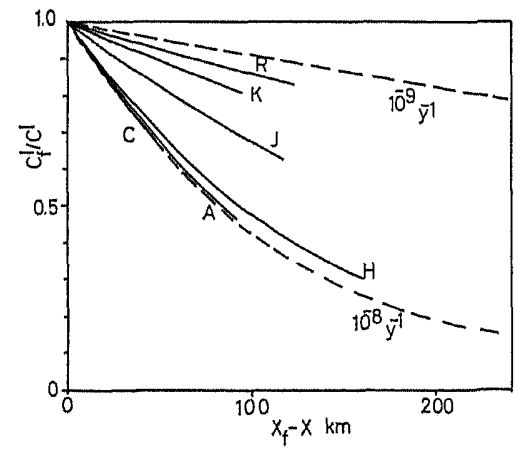

Fig. 9. Theoretical change of $\mathrm{K}_{2} \mathrm{O}$-content in the liquid against the distance from the volcanic front, and the lateral variations of $\mathrm{K}_{2} \mathrm{O}$-content in basaltic andesite $\left(\mathrm{SiO}_{2}=55 \mathrm{wt} \%\right.$ ) of Ryukyus (R), Kurile-Kamchatka (K), Java (J), Central America (C), Aleutian (A) and Northeast Japan (H) (cited from Nreuson and Storber (1973)). Abbreviations are follows: $C_{\mathrm{f}}^{1} ; \mathrm{K}_{2} \mathrm{O}$-content at the volcanic front, $x_{\mathrm{f}}-x$; distance from the volcanic front. 
ations of $\mathrm{K}_{2} \mathrm{O}$-content in basaltic andesite obtained by them are shown in Fig. 9. It is suggested that the range of chemical variation of natural rocks is just in the calculated range, and the theoretical change is quite similar to the lateral variation of magma chemistry of volcanic rocks.

If the lateral change of $\mathrm{K}_{2} \mathrm{O}$-content of the Island Arc volcanism can be interpreted by the zone refining model discussed here, other components such as $\mathrm{FeO}, \mathrm{Na}_{2} \mathrm{O}$ and $\mathrm{Al}_{2} \mathrm{O}_{3}$, of which the ratio, $k$, is smaller than 1 , should be enriched in volcanic rocks with increasing distance from the volcanic front. But, considering that $k$ is close to 1 , the amplification factor of such components is less than that of $\mathrm{K}_{2} \mathrm{O}$ by a factor of 10 or less. Therefore, the ratio of $C_{\mathrm{f}} 1 / C^{1}$ of $\mathrm{FeO}$ and $\mathrm{Na}_{2} \mathrm{O}$ may be less than 0.9 at the distance of 100 $\mathrm{km}$ from the volcanic front.

Figure 9 also suggests that the eruption rate of island arcs of Java, Kurile-Kamchatka, and Ryukyu is less than that of island arcs of Central America, Aleutian, and Northeast Japan, if the mean velocity of the return flow of the upper mantle is in the same order.

\section{Conclusion}

The dislocation densities of olivine grains from Ichinomegata, Sannomegata, OkiDogo, Hamada and Takashima are in the range of $10^{6}-10^{7} \mathrm{~cm}^{-2}$. The data lead to the following conclusions :

1) The actual differential stress of the upper mantle is in the range of 100-300 bars, and it is similar to that of the Pacific Plate deduced from spinel lherzolite xenoliths of Salt Lake of Hawaii.

2) The strain rate in the mantle from 30 to $100 \mathrm{~km}$ depth is less than $10^{-15} \mathrm{sec}^{-1}$, and it is constant around $10^{-13}-10^{-2} \mathrm{sec}^{-1}$ from 100 to $200 \mathrm{~km}$ depth.

3) Convective flow is inferred and it is composed of drag and return flow induced by descending slab.

4) Return flow of the upper mantle causes the lateral change of magma chemistry and upper mantle materials due to continuous upward outflow of the partially molten liquid from the moving upper mantle.

I thank Drs. I. Kushiro, S. Aramaki, Y. Nakamura and S. Karato of University of Tokyo for many discussions. I am also indebted to Drs. T. Fujii, H. Fukuyama and E. Takahashi of University of Tokyo for discussions.

\section{REFERENCES}

Aokr, K., Materials derived from upper mantle-Ejected accidental fragments from Ichinomegata crater, Kagaku, 42, 615-621, 1973 (in Japanese).

Carter, N.L. and H.G. AveLallemant, High temperature flow of dunite and peridotite, Geol. Soc. Am. Bull, 81, 2181-2202, 1970.

Durham, W.B. and C. Goetze, Plastic flow of oriented single crystals of olivine. 1. Mechanical data, J. Geophys. Res., 82, 5737-5753, 1977.

Durfiam, W.B., C. Goetze, and B. Blake, Plastic flow of oriented single cyrstals of olivine. 2. Observation and interpretation of the dislocation structures, $J$. Geophys. Res., 82, 5755-5770, 1977.

Fujr, T., Petrology of Hamada nephelinite and associated ultramafic inclusions, $\mathrm{PhD}$ Thesis of University of Tokyo, 1974.

Fujisawa, H., Temperature and discontinuities in the transition layer within the earth's mantle. Geophysical application of the olivine-spinel transition in the $\mathrm{Mg}_{2} \mathrm{SiO}_{4}-\mathrm{Fe}_{2} \mathrm{SiO}_{4}$ system, J. Geophys. Res., 73, 3281-3294, 1968.

Goetze, C. and D.L. Kohlstedt, Laboratory study of dislocation climb and diffusion in olivine, J. Geophys. Res., 78, 5961-5971, 1973. 
GRIGGs, D.T., A model of hydrolytic weakening in quarts, J. Geophys. Res., 79, 1653-1661, 1974.

Gueguen, Y., Dislocations in mantle peridotite nodules, Tectonophysics, 39, 231-254, 1977.

Hasebe, K., N. FujIr, and S. UyedA, Thermal process under island arcs, J. Geophys. Res., 10, 1-13, 1970.

Hatherton, T. and W.R. Drokrnson, The relationship between andesitic volcanism and seismicity in Indonesian, the Lesser Antilles and other island arcs, J. Geophys. Res., 74, 5301-5310, 1969.

Hüther, W. and B. RePpich, Dislocations structure during creep of MgO single crystals, Phil. Mag., 28, 363$371,1973$.

Karato, S., Rheological properties of the materials composing the earth's mantle, PhD Thesis of the University of Tokyo, 1977.

Kohlstedt, D.L. and C. Goetze, Low stress high temperature creep in olivine single crystals, J. Geophys. Res., 79, 2045-2051, 1974.

KoHLSTEDT, D.L. and J.B. VANDER SANDE, An electron microscopy study of naturally occurring oxidation produced precipitates in iron-bearing olivines, Contrib. Mineral. Petrol., 53, 13-24, 1975.

Kuno, H. and K. Aokr, Chemistry of ultramafic nodules and their bearing on the origin of basaltic magmas, Phys, Earth Planet. Inter., 3, 273-301, 1970.

Kushiro, I. and H.S. Yoder, Anorthite-forsterite and anorthite-enstatite reactions and their bearing on the basalt-eclogite transformation, $J$. Petrol., 7, 337-362, 1966.

Kushiro, I., Y. Syono, and S. Aкrмoto, Melting of a peridotite at high pressures and high water pressures, J. Geophys. Res., 73, 6023-6029, 1968.

MCGREGor, I.D., The system $\mathrm{MgO}-\mathrm{Al}_{2} \mathrm{O}_{3}-\mathrm{SiO}_{2}$ : Solubility of $\mathrm{Al}_{2} \mathrm{O}_{3}$ in enstatite for spinel and garnet peridotite compositions, Am. Mineral., 59, 110-119, 1974.

Nabarro, F.R.N., Theory of Crystal Dislocations, 821 pp., Clarendon Press, Oxford, 1967.

Nakamura, K., Preliminary estimate of global volcanic production rate, in The Utilization of Volcano Energy (Proc. of a U. S.-Japan Coop. Sci. Semin.), edited by J.L. Golp and A.S. Furumoto, pp. 273-285, 1974.

NiELSON, D.R. and R.E. SToiber, Relationship of potassium content in andesitic lavas and depth to the seismic zone, J. Geophys. Res., 78, 6887-6892, 1973.

Obata, M., Petrography and petrogenesis of ultramafic inclusions from Takashima, northern Kyushu, Japan, Ms. Thesis of Kanazawa University, 1972.

Raleigh, C.B. and S.H. Krrix, Creep in the upper mantle, Mineral. Soc. Am. Spec. Pap., 3, 113-121, 1970.

Sleep, N. and M.N. Toksoz, Evolution of magrinal basins, Nature, 233, 548-550, 1971.

Stocker, R.L. and M.F. Ashry, On the rheology of the upper mantle, Rev. Geophys. Space Phys., 11, 391-426, 1973.

Streb, G. and B. Reppich, The steady state cleformation and dislocation structure of pure and Mg-doped LiF single crystals. II. Etch-pit studies of dislocation structure, Phys. Stati. Solidi, 16a, 493-505, 1973.

Sugimura, A., Island arcs. in Physics of the Earth, edited by Phys. Soc. Japan, Maruzen, pp. 189-222, 1974.

TakAfrashr, E., Ultramafic xenoliths of alkali basalt, Oki-Dogo Islands in the Japan Sea, Ms. Thesis of University of 'Tokyo, 1976.

Toksöz, M.N., J.W. Minear, and B.R. JuLIAN, Temperature field and geophysical effects of a downgoing slab, J. Geophys. Res., 76, 1113-1138, 1971.

Toriumi, M., Dislocation structure of olivine in the Mt. Higashi Akaishi dunite mass in the Sambagawa metamorphic terrane of Japan, J. Geol. Soc. Jpn., 84, 299-308, 1978.

Tortumi, M. and S. Karato, Experimental studies on the recovery process of deformed olivines and the mechanical state of the upper mantle, Tectonophysics, 49, 79-95, 1978.

Weertman, J., Dislocation climb theory of steady state creep, Trans. Am. Soc. Met., 61, 681-694, 1968.

Weertman, J., The creep strength of the earth's mantle, Rev. Geophys. Space Phys., 8, 145-168, 1970. 